\title{
Societal Protection and Population Vulnerability: Key Factors in Explaining Community-Level Variation in Fatal Fires Involving Older Adults in Sweden
}

\author{
Finn Nilson (D*, Centre for Societal Risk Research, Karlstad University, \\ Karlstad, Sweden and Health Economics and Policy, School of Public \\ Health and Community Medicine, University of Gothenburg, Gothenburg, \\ Sweden \\ Carl Bonander, Centre for Societal Risk Research, Karlstad University, 65188 \\ Karlstad, Sweden
}

Received: 8 January 2020/Accepted: 11 May 2020

\begin{abstract}
Based on evidence from previous studies, fire mortality rates among older adults on a local level seem to be related two dimensions; population vulnerability and societal protection. In this paper, we investigate the magnitude of the impacts of variation along these two dimensions on the rate of fatal fires involving at least one older adult $(65+$ years $)$ in Swedish municipalities. Our empirical strategy involves using principal components analysis to estimate the two dimensions based on data on the health of the older population, factors related to municipal rescue service efficiency, as well as other factors that may indirectly effect efficiency (such as urbanization rates and economic conditions). We then use Poisson regression models to study how mortality rates vary with changes along each dimension while keeping the other constant. The results support previous evidence suggesting that an efficient rescue service is important for low fire mortality rates. However, we also find evidence that variations in the vulnerability of the older population may play an equally important role. As such, the results indicate while improved societal protection is important in order to reduce fire-related mortality rates, merely focusing on these aspects will not eliminate the risk-increasing aspect of population vulnerability. In turn, this implies a need for a multifaceted approach to local fire mortality prevention that targets both rescue service efficiency and population vulnerability.
\end{abstract}

Keywords: Rescue services, Elderly, Efficiency

\footnotetext{
*Correspondence should be addressed to: Finn Nilson, E-mail: finn.nilson@kau.se
} 


\section{Introduction}

In high-income countries, fire-related mortality has increasingly become an issue primarily concerned with those over 65 years [1-3]. Coupled with the demographic development and projected increases in the percentage of older people in the population [4], the overrepresentation of older people in the risk of fire-related deaths is a problem that requires attention in order to minimise the risk of increasing trends of fire-related deaths [5].

Although the risk of fire initiation appears to be lower among older adults compared to younger age groups [6], the risk of fire-related mortality per fire in the older age groups is very high, most likely due to a decreased ability to evacuate or extinguish the fire, caused by age-related physical and cognitive decline [7-9].

The importance of individual vulnerability in explaining fire-related mortality is well-known with several studies having shown the increased risk amongst those living alone [2, 10], belonging to an ethnic minority [11, 12], having low educational attainment $[11,13]$, as well as having a low disposable income, receiving social allowance, being unemployed and receiving health-related early retirement pension [10, 14, 15]. nterestingly, many of these socio-demographic differences have been observed since the 1970s [16, 17] though seem to have become even more pronounced in recent years [14].

Of these vulnerability factors, living alone has been shown to be the most important. Conversely, therefore, the issue of co-living has been shown to be the most important protective factor for older adults [10]. Despite this, however, the current societal trend in a large majority of high-income countries is that older, multi-ill adults are increasingly living alone [18] and less in multigenerational households [19]. Also, evidence suggests that this societal development will continue [20], not least given that few economic incentives are provided to encourage co-living and that many older adults want to live alone [21]. As a consequence, it is feared that fire-related mortality among older adults can increase considerably without appropriate interventions.

Whilst increasing physical and cognitive capabilities as well as co-living are factors that are primarily connected to the individual, from a societal, reactive perspective, a prioritized fire mortality intervention is a well-functioning rescue service. More specifically, as shown in previous studies [22], the response time from the rescue services is crucial in reducing the number of deaths. However, quick response times require high geographical and personnel coverage and thereby higher costs. In Sweden, as in many other countries, fire protection efforts are organized at the local municipal level meaning that the financial situation for rescue services is dependent upon local taxes that in turn are dependent upon a large working population. Coupled with general reductions in the number of attended fires, questions regarding the cost-effectiveness of full-time municipal rescue services have been raised (see for example [23]), therefore leading to a promotion of replacing more expensive full-time organizations with part-time organizations. Although other societal institutions (such as private security companies or healthcare deliverers) can be used to assist in rapid response, the effects 
of these types of interventions on the risk of death appears to be relatively low [24].

It can therefore be hypothesized that two dimensions; an individual and societal, exists in terms of determining fire mortality rates among older adults on a municipality level. The individual dimension concerns the innate vulnerability of the older population whilst the societal dimension concerns the societal protection provided by the municipality. A deeper understanding of the relationship and relative importance between these two factors is crucial, especially when societies with limited budgets need to determine which preventative strategies to use and whether one or both aspects should be prioritized. This paper, therefore, aims to investigate this relationship using Sweden as a case.

\section{Methods and Materials}

We employed an ecological design with Swedish municipalities as the unit of analysis. Our outcome measure was the number of fatal fires involving at least one older adult (65 + years) recorded over the period 1999-2015 (16 years) per 100.000 person-years of observation. Our study relies on data from official sources. The outcome data was obtained from the Swedish Civil Contingencies Agency, and the population denominator used to quantify rates per person-years was obtained from Statistics Sweden. To collect relevant covariate data, we screened available databases and registers for municipality-level data relating to rescue service performance or organizations, the health of the older population and other municipal factors that may directly or indirectly affect fire mortality rates. Specifically, we began by reviewing the Municipality and County Council Database (Kolada by Swedish acronym), which collates data from multiple official sources and surveys conduct in Sweden. We also screened databases held by relevant authorities, including the Swedish Civil Contingencies Agency, The National Board of Health and Welfare and Statistics Sweden. After compiling a list of factors available in these databases, we discussed their potential relation to fire mortality rates at the municipal level with the reference group consisting of eight leading fire safety experts and practitioners familiar with the Swedish context. After this discussion, we arrived at the covariates, defined and detailed along with their sources, in Table 1. When possible, we extracted data for the period 19992015. In some cases, data was unavailable for the entire period or only for a period that partially overlaps with our outcome data. For these variables, we extracted data from as many years as possible within, or close to, the period 1999-2015 (see Table 1 for details).

Many covariates were highly collinear (see Appendix: Table 4), so we opted for a dimensionality reduction approach to reduce the number of variables into principal components. Specifically, we used principal components analysis (PCA), followed by Varimax rotation [25]. We selected the number of components to retain by visual inspection of a scree plot (see Supplementary Figure A1 for details), after confirming that the data was suitable for PCA (Kaiser-Meyer-Olkin's measure of sampling adequacy: .783; Bartlett's test of sphericity: $\chi^{2}(45)$ : 948.7, 


\section{Table 1}

Covariate Information with Descriptive Statistics and Data Sources

\begin{tabular}{|c|c|c|c|c|c|c|c|}
\hline Variable & $\begin{array}{l}\mathrm{N} \\
\text { obs. }\end{array}$ & Mean & SD & Min & Max & Period & Source \\
\hline $\begin{array}{l}\text { Share living alone, } \\
65+\text { years }(\%)\end{array}$ & 290 & 35.1 & 3.4 & 24.2 & 45.1 & $\begin{array}{c}2011- \\
2015\end{array}$ & Statistics Sweden \\
\hline $\begin{array}{l}\text { Fall injury incidence (hospital } \\
\text { admissions per } 100.000 \\
\text { person-years) }\end{array}$ & 290 & 3345.2 & 650.9 & 2085.3 & 5956.9 & $\begin{array}{l}2010- \\
2015\end{array}$ & $\begin{array}{l}\text { The National } \\
\text { Board of Health } \\
\text { and Welfare }\end{array}$ \\
\hline $\begin{array}{l}\text { Gross regional product (GRP) } \\
\text { per capita }\end{array}$ & 290 & 302.8 & 123.3 & 123.3 & 1228.4 & $\begin{array}{c}2012- \\
2015\end{array}$ & Statistics Sweden \\
\hline $\begin{array}{l}\text { Dependency ratio (ratio of } \\
\text { inhabitants } 0-19 \text { years and } \\
65+\text { to } 20-64 \text { years, } \\
\text { logarithmic scale) }\end{array}$ & 290 & -0.2 & 0.1 & -0.7 & 0.1 & $\begin{array}{l}1999- \\
2015\end{array}$ & Statistics Sweden \\
\hline $\begin{array}{l}\text { Share living in nursing homes, } \\
65+\text { years }(\%)\end{array}$ & 290 & 5.2 & 1.2 & 2.7 & 8.6 & $\begin{array}{l}2007- \\
2012\end{array}$ & $\begin{array}{l}\text { The National } \\
\text { Board of Health } \\
\text { and Welfare }\end{array}$ \\
\hline $\begin{array}{l}\text { Share with home care service, } \\
65+\text { years }(\%)\end{array}$ & 290 & 8.7 & 1.7 & 4.5 & 13.2 & $\begin{array}{l}2007- \\
2012\end{array}$ & $\begin{array}{l}\text { The National } \\
\text { Board of Health } \\
\text { and Welfare }\end{array}$ \\
\hline $\begin{array}{l}\text { Rescue service response time } \\
\text { (median) }\end{array}$ & 287 & 12.8 & 3.1 & 7.8 & 28.1 & $\begin{array}{c}2010- \\
2015\end{array}$ & SOS Alarm \\
\hline Share living in urban areas $(\%)$ & 290 & 74.3 & 14.5 & 31.0 & 100.0 & $\begin{array}{c}2005- \\
2015\end{array}$ & Statistics Sweden \\
\hline $\begin{array}{l}\text { Population density (inhabitants } \\
\text { per } 1000 \mathrm{~km}^{2} \text {, logarithmic } \\
\text { scale) }\end{array}$ & 290 & 3.3 & 1.7 & -1.4 & 8.5 & $\begin{array}{l}2011- \\
2015\end{array}$ & Statistics Sweden \\
\hline $\begin{array}{l}\text { Share of applications with } \\
\text { longer than } 90 \text { days wait time } \\
\text { (nursing homes) }(\%)\end{array}$ & 258 & 20.6 & 16.3 & 0.0 & 97.0 & $\begin{array}{c}2014- \\
2018\end{array}$ & $\begin{array}{l}\text { Swedish Associa- } \\
\text { tion of Local } \\
\text { Authorities and } \\
\text { Regions }\end{array}$ \\
\hline
\end{tabular}

$p<0.001)$. We used Poisson regression to quantify incidence rate ratios for each covariate and to analyze how and if the identified principal components relate to the outcome. The PCA was conducted in SPSS Version 25, and the results were exported to Stata version 15.1 for the remaining analyses.

\section{Results}

A total of 669 fatal fires involving at least one person over the age of 65 years was recorded in the data, which corresponds to an expected rate of 2.36 fatal fires 100.000 person-years of observation. However, the observed rate varies from 0 to 16.92 across municipalities (Fig. 1). 


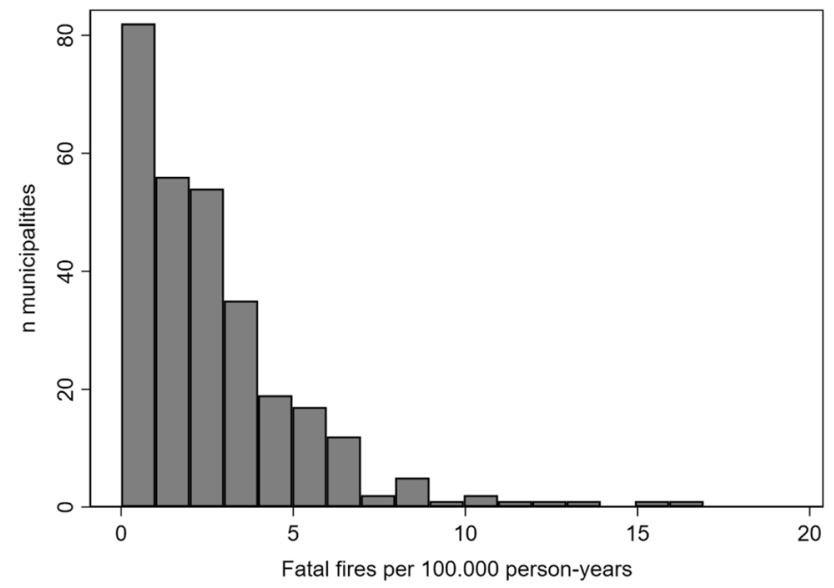

\section{Figure 1. The number of fatal fires per municipality.}

Table 2, Column I shows how each covariate is associated with the rate of fatal fires involving older adults without accounting for the other factors in the data. The unadjusted estimates show that the share of the population living in urban areas ("urbanization") is negatively correlated with mortality rates. On the other hand, we observed positive correlations with rescue service response times and fall injury incidence rates, as well as the shares of the older population living alone, having home care or living in nursing homes. Together, these results imply that rescue service organizational factors and context (e.g., distance) matter and that the vulnerability of the population does as well.

The coefficients from a multiple regression including all covariates were generally imprecise. We present the results from this analysis in Table 2, Column II, but advise caution in interpreting the results for each factor individually given the strong collinearity between many of the factors in the data. For instance, Spearman's rho for the correlation between urbanization and median response time is -0.7 , probably because the travel distance is smaller in urban areas. It is therefore difficult for the model to separate the effects of these factors in our data. We found correlations of similar magnitude for the population variables, indicating that they are proxies for the same underlying phenomena (e.g., the vulnerability of the population) (Appendix: Table 4), which motivates a dimensionality reduction approach.

Using the 256 municipalities with complete covariate and outcome data, the PCA resulted in two components which we interpreted as (1) (municipal) urbanization and (rescue service) efficiency and (2) population vulnerability (the factor loadings for each covariate is presented in Table 3, and the scree plot used to determine the number of components is presented in Supplementary Figure A1). Together, these components explain $56 \%$ of the variance in the covariate data.

Figure 2 shows how the two components, divided into quintile groups, relate to the outcome while keeping the other component constant at its median value (estimated using a Poisson regression model with the two [quintile-grouped] compo- 


\section{Table 2}

Univariable and Multivariable Poisson Regression Results Showing the Unadjusted and Adjusted Association Between Each Predictor and the Incidence of Fatal Fires Per Person-Year

\begin{tabular}{|c|c|c|c|c|}
\hline \multirow[b]{2}{*}{ Variable } & \multicolumn{2}{|l|}{ Univariate models } & \multicolumn{2}{|l|}{ Multivariable model } \\
\hline & $\begin{array}{l}\text { Estimated percentage } \\
\text { change in risk per one } \\
\text { unit increase in covari- } \\
\text { ate }\end{array}$ & $\begin{array}{c}p \\
\text { value }\end{array}$ & $\begin{array}{l}\text { Estimated percentage } \\
\text { change in risk per one } \\
\text { unit increase in covari- } \\
\text { ate }\end{array}$ & $\begin{array}{c}p \\
\text { value }\end{array}$ \\
\hline Share living in urban areas $(\%)$ & $\begin{array}{l}-0.66 \\
(-1.19,-0.12)\end{array}$ & 0.02 & $\begin{array}{l}-1.45 \\
(-2.53,-0.36)\end{array}$ & 0.01 \\
\hline $\begin{array}{l}\text { Fall injury incidence (hospital } \\
\text { admissions per } 100.000 \text { person- } \\
\text { years) }\end{array}$ & $\begin{array}{l}0.01 \\
(0.00,0.02)\end{array}$ & 0.01 & $\begin{array}{l}0.02 \\
(0.00,0.03)\end{array}$ & 0.06 \\
\hline $\begin{array}{l}\text { Dependency ratio (ratio of } \\
\text { inhabitants } 0-19 \text { years and } \\
65+\text { to } 20-64 \text { years, logarith- } \\
\text { mic scale) }\end{array}$ & $\begin{array}{l}-3.33 \\
(-44.05,67.05)\end{array}$ & 0.90 & $\begin{array}{l}-51.54 \\
(-85.06,57.23)\end{array}$ & 0.23 \\
\hline $\begin{array}{l}\text { Gross regional product (GRP) } \\
\text { per capita }\end{array}$ & $\begin{array}{l}0.03 \\
(-0.01,0.07)\end{array}$ & 0.17 & $\begin{array}{l}0.01 \\
(-0.07,0.09)\end{array}$ & 0.86 \\
\hline $\begin{array}{l}\text { Population density (inhabitants } \\
\text { per } 1000 \mathrm{~km}^{2} \text {, logarithmic } \\
\text { scale) }\end{array}$ & $\begin{array}{l}-2.47 \\
(-6.21,1.41)\end{array}$ & 0.21 & $\begin{array}{l}-3.42 \\
(-11.42,5.30)\end{array}$ & 0.43 \\
\hline $\begin{array}{l}\text { Rescue service response time } \\
\text { (median) }\end{array}$ & $\begin{array}{l}3.29 \\
(0.16,6.51)\end{array}$ & 0.04 & $\begin{array}{l}-1.47 \\
(-6.60,3.95)\end{array}$ & 0.59 \\
\hline $\begin{array}{l}\text { Share of applications with longer } \\
\text { than } 90 \text { days wait time (nurs- } \\
\text { ing homes) (\%) }\end{array}$ & $\begin{array}{l}-0.35 \\
(-0.87,0.17)\end{array}$ & 0.19 & $\begin{array}{l}-0.01 \\
(-0.58,0.56)\end{array}$ & 0.97 \\
\hline $\begin{array}{l}\text { Share with home care service, } \\
65+\text { years }(\%)\end{array}$ & $\begin{array}{l}4.98 \\
(0.64,9.50)\end{array}$ & 0.02 & $\begin{array}{l}2.87 \\
(-3.06,9.16)\end{array}$ & 0.35 \\
\hline $\begin{array}{l}\text { Share living in nursing homes, } \\
65+\text { years }(\%)\end{array}$ & $\begin{array}{l}6.42 \\
(-0.94,14.32)\end{array}$ & 0.09 & $\begin{array}{l}-0.16 \\
(-8.74,9.22)\end{array}$ & 0.97 \\
\hline $\begin{array}{l}\text { Share living alone, } 65+\text { years } \\
(\%)\end{array}$ & $\begin{array}{l}2.46 \\
(0.54,4.41)\end{array}$ & 0.01 & $\begin{array}{l}1.33 \\
(-2.49,5.31)\end{array}$ & 0.50 \\
\hline
\end{tabular}

The estimates are based on the coefficients from Poisson regression models with the logarithm of the sum of person-years over the entire period as an offset. The outcome is the number of fatal fires involving at least one person over the age of 65 years. The coefficients were converted to percentage changes using $(\exp (\mathrm{B})-1)^{*} 100$, where $B$ is the regression coefficient. Confidence intervals $(95 \%)$ are presented in parentheses

nents as independent variables). As might be expected, the results show that higher urbanization and efficiency is associated with lower fire mortality rates, whereas the vulnerability of the older population is associated with higher rates. In terms of magnitude, the rate difference is -0.8 per 100.000 person-years between the highest and lowest quintile group on the urbanization component ( $-33 \%$ in relative terms) and +1.1 per 100.000 person-years between the highest and lowest group on the vulnerability component $(+56 \%)$. The difference is statistically significant ( $p=.008$ in both cases). 


\section{Table 3}

Results from the Principal Components Analysis

\begin{tabular}{|c|c|c|}
\hline & \multicolumn{2}{|c|}{ Principal components } \\
\hline & $\begin{array}{l}\text { (1) Urbanization } \\
\text { and efficiency }\end{array}$ & $\begin{array}{l}\text { (2) Population } \\
\text { vulnerability }\end{array}$ \\
\hline Share living alone, $65+$ years $(\%)$ & & 0.83 \\
\hline $\begin{array}{l}\text { Fall injury incidence (hospital admissions per } 100.000 \text { per- } \\
\text { son-years) }\end{array}$ & & 0.70 \\
\hline $\begin{array}{l}\text { Share of applications with longer than } 90 \text { days wait time } \\
\text { (nursing homes) }(\%)\end{array}$ & 0.21 & \\
\hline Gross regional product (GRP) per capita & 0.44 & 0.64 \\
\hline $\begin{array}{l}\text { Dependency ratio (ratio of inhabitants } 0-19 \text { years and } \\
65+\text { to } 20-64 \text { years, logarithmic scale) }\end{array}$ & -0.82 & \\
\hline Share living in nursing homes, $65+$ years $(\%)$ & -0.48 & 0.51 \\
\hline Share with home care service, $65+$ years $(\%)$ & & 0.56 \\
\hline Rescue service response time (median) & -0.80 & \\
\hline Share living in urban areas $(\%)$ & 0.86 & \\
\hline $\begin{array}{l}\text { Population density (inhabitants per } 1000 \mathrm{~km}^{2} \text {, logarithmic } \\
\text { scale) }\end{array}$ & 0.89 & \\
\hline
\end{tabular}

The component loading are based on principal components analysis (PCA) followed by Varimax rotation. Small loadings (<.20) are suppressed. Results for Kaiser-Meyer-Olkin's measure of sampling adequacy: .783; Bartlett's test of sphericity: $\chi 2(45): 948.7, p<0.001$

As a final analysis, we plotted the components in a two-way scatter plot, including reference lines that divide the sample of municipalities into four groups: (1) high urbanization-low vulnerability, (2) high urbanization-high vulnerability, (3) low urbanization-high vulnerability and (4) low urbanization-low vulnerability (Fig. 2). We then calculated the observed mortality rates per group. As shown in the plot, we found the lowest rates in the high urbanization-low vulnerability group and the highest in the low urbanization-high vulnerability group. In fact, the rate reduction from the high-risk group to the low-risk group is larger than the rate reductions in the "medium-risk" (lower left and upper right) quadrants combined, which implies an interaction effect in the sense that societal protection efforts may be more efficient in low vulnerability populations (Fig. 3).

\section{Discussion}

Overall, the results from this study imply that there are (at least) two separate, underlying components (individual vulnerability and societal protection) that determine fire-related mortality rates among older adults at the local level. While it is ill-advised to infer causality from observational data, prior evidence supports the plausibility of these two mechanisms. Importantly, the results suggest that while societal protection, through for example short response times, does lower the fire-related mortality rates, they do not eliminate the risk-increasing aspect of individual vulnerability. 
(1) Urbanization and efficiency

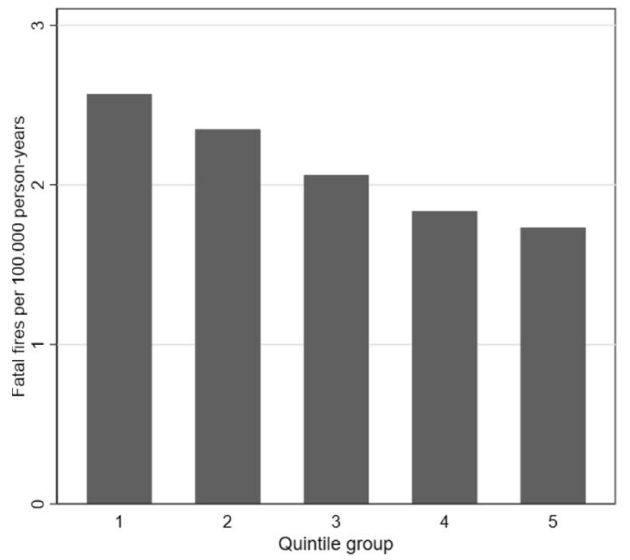

(2) Population vulnerability

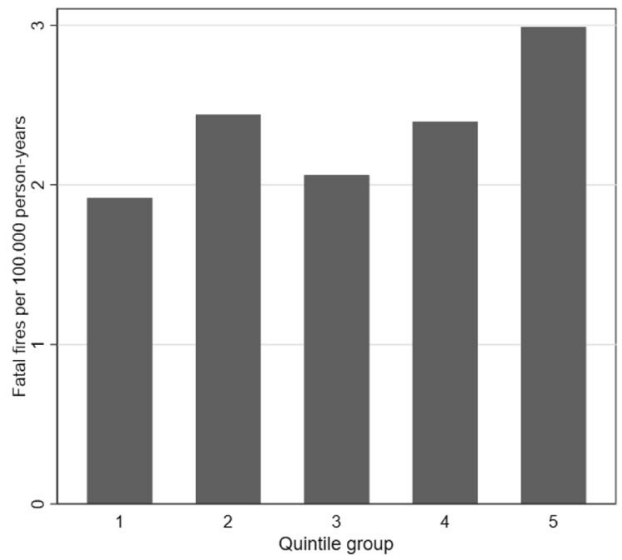

Figure 2. Expected number of fatal fires per 100.000 person-years involving at least one person over the age of 65 years depending on the municipalities score on (1) urbanization and efficiency and (2) population vulnerability. In each subplot, the other component is held constant at its mean.

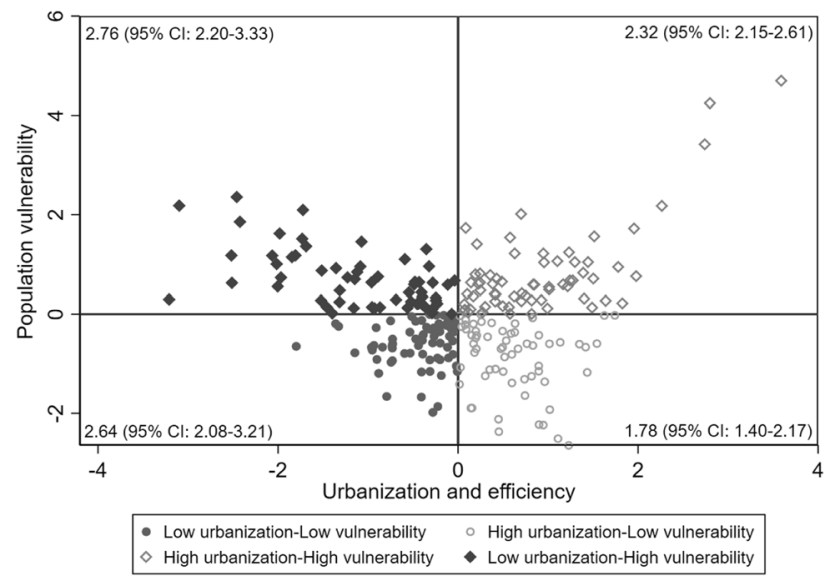

Figure 3. Scatterplot showing the distribution of municipalities across the two dimensions (population vulnerability; urbanization and efficiency) identified in the principal components analysis. The data is split into four groups. The numbers reported in each quadrant represents the group-wise rate of fatal fires (per 100.000 personyears) involving at least one person over the aged of 65 years. 
From a public health perspective, the importance of sociodemographic risk factors and individual vulnerability in explaining inequality in mortality is well established, as are the necessary preventative measures, for example increasing the general educational level, increasing health literacy and improving access to healthcare. General public health measures, such as those aimed at increasing physical activity and sense of coherence in the population, may also be potentially important interventions, provided that they lead to lower individual vulnerability and increased co-living.

While decreasing individual vulnerability is an important long-term goal, not merely from a fire-related mortality perspective, such interventions take time. Therefore, in order to reduce fire-related mortality rates amongst older adults in the short term, other interventions need to be promoted. Previous studies have shown the importance of rescue service response times, [22] and although there is evidence that the presence of smoke alarms can compensate for slower response times [26], for many older adults escaping a fire can be exceedingly difficult. Therefore, in terms of the older adult population, response times is likely to be crucial, especially considering that a large percentage of older adults in Sweden have functioning smoke alarms [27].

Despite the importance, however, in order to accomplish a high level of service as required, the societal costs risk being high. This is further complicated by the fact that Sweden, in similarity to other high-income countries, has a high urbanization rate, particularly among younger, well-educated individuals [28]. This urbanization pattern has a dramatic effect on the financial status of rural municipalities [29] meaning that rural communities are therefore more likely to be forced into cost-cutting. The municipal organization of rescue services, as well as public health interventions, could thereby be an organizational barrier to reducing firerelated mortality among older adults.

There are some limitations to our study worth mentioning. Firstly, the urbanization process could also have other implications on the fire mortality risk that have not been possible to include in this study. For example, sprinkler systems are more likely to exist in newer and larger multi-home buildings than in one-family homes [30] and given that high-rise and newer buildings are predominantly built in urban areas, it could be more likely that passive safety is higher in urban areas than in rural areas. However, according to the Swedish Contingency Agency, only $0.4 \%$ of residential properties in Sweden have sprinkler systems [31]. As such, this will unlikely affect our results.

Secondly, a potential problem with our data is that it is collected from secondary sources and may therefore vary in quality. The mortality data also covers a longer period than many of the covariates, which may introduce some bias if there are strong municipality-specific time trends. However, the precision of the estimates would be too low to provide any meaningful information if we had used the same periods as the covariates. It also appears unlikely that the observed associations can be attributed entirely to such artefacts, especially given the theoretical plausibility of the observed associations. However, we cannot rule this out, and replication in other settings is therefore strongly warranted. Our results motivate further research and focus on societal efforts both in the short- and long-term perspective. 
On a broader scale, the results also imply that public health agencies and rescue service organizations could benefit from working together to decrease fire mortality rates at the local level, especially in communities with vulnerable populations.

\section{Conclusion}

Our analyses suggest that the level of individual vulnerability in a municipality and the level of societal protection are equally important in explaining municipal differences in fire mortality amongst older adults. From a societal prevention perspective, the results suggest that while improved societal protection would reduce fire-related mortality rates, merely focusing on these aspects will not eliminate the risk-increasing aspect of individual vulnerability. Not least, this is apparent in regards to fire-related deaths that are related to smoking and individuals who are alcohol-, drug- or disability-impaired. These cases are often the result of small, undramatic fires meaning that sprinklers and/or fire alarms (and thereby the response of rescue services) are relatively ineffective [32]. Therefore, both societal protection and individual vulnerability needs to be improved in order to reduce fire mortality rates.

\section{Acknowledgements}

Open access funding provided by Karlstad University. The authors gratefully thank The Swedish Fire Research Board for financial support (Project Number 202-171). The funding source had no role in the design of the study, the analysis and interpretation of the data or the writing of, nor the decision to publish, the manuscript.

\section{Open Access}

This article is licensed under a Creative Commons Attribution 4.0 International License, which permits use, sharing, adaptation, distribution and reproduction in any medium or format, as long as you give appropriate credit to the original author(s) and the source, provide a link to the Creative Commons licence, and indicate if changes were made. The images or other third party material in this article are included in the article's Creative Commons licence, unless indicated otherwise in a credit line to the material. If material is not included in the article's Creative Commons licence and your intended use is not permitted by statutory regulation or exceeds the permitted use, you will need to obtain permission directly from the copyright holder. To view a copy of this licence, visit http://creat ivecommons.org/licenses/by $/ 4.0 /$.

\section{Appendix}

See Table 4. 


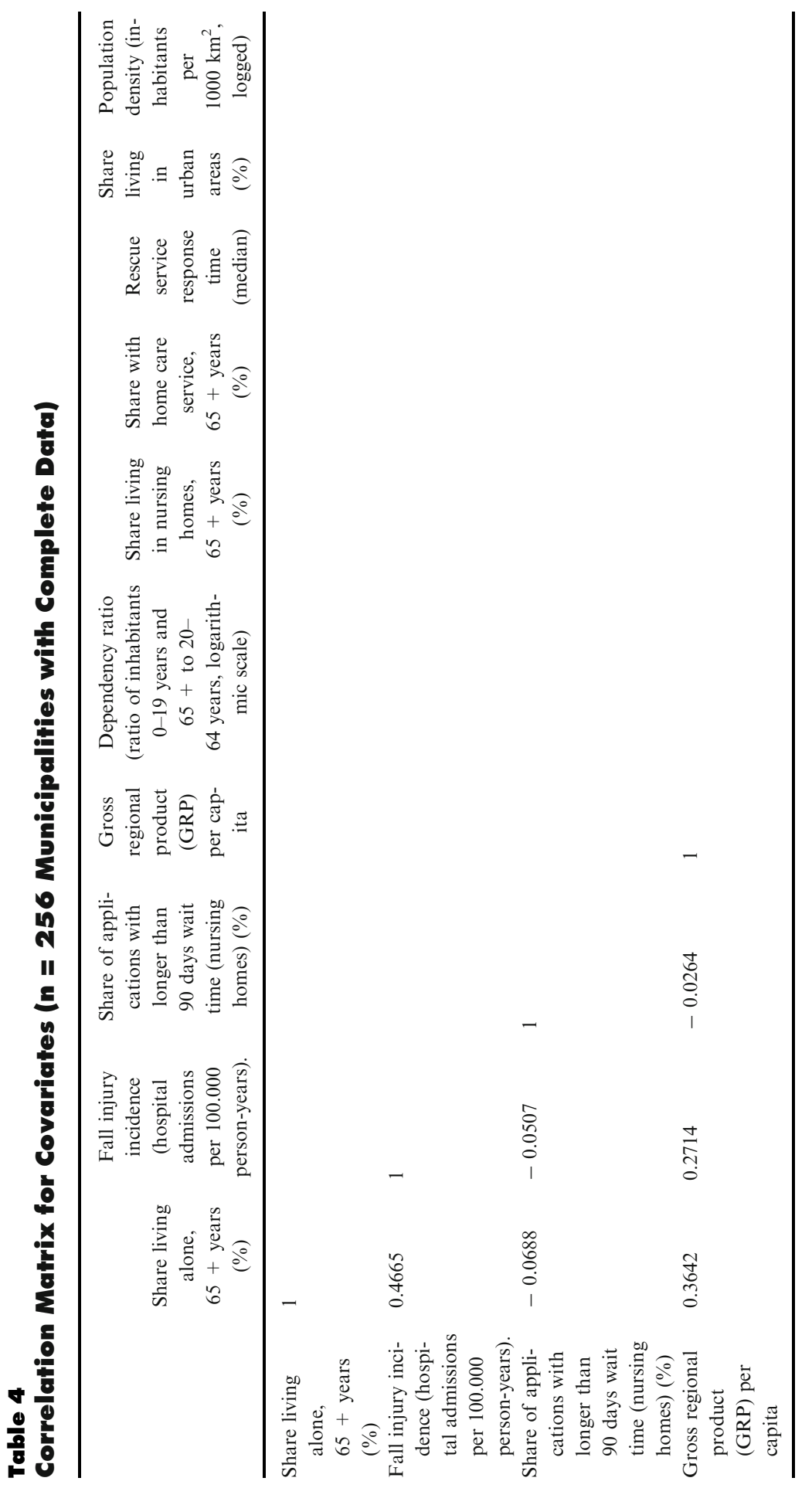




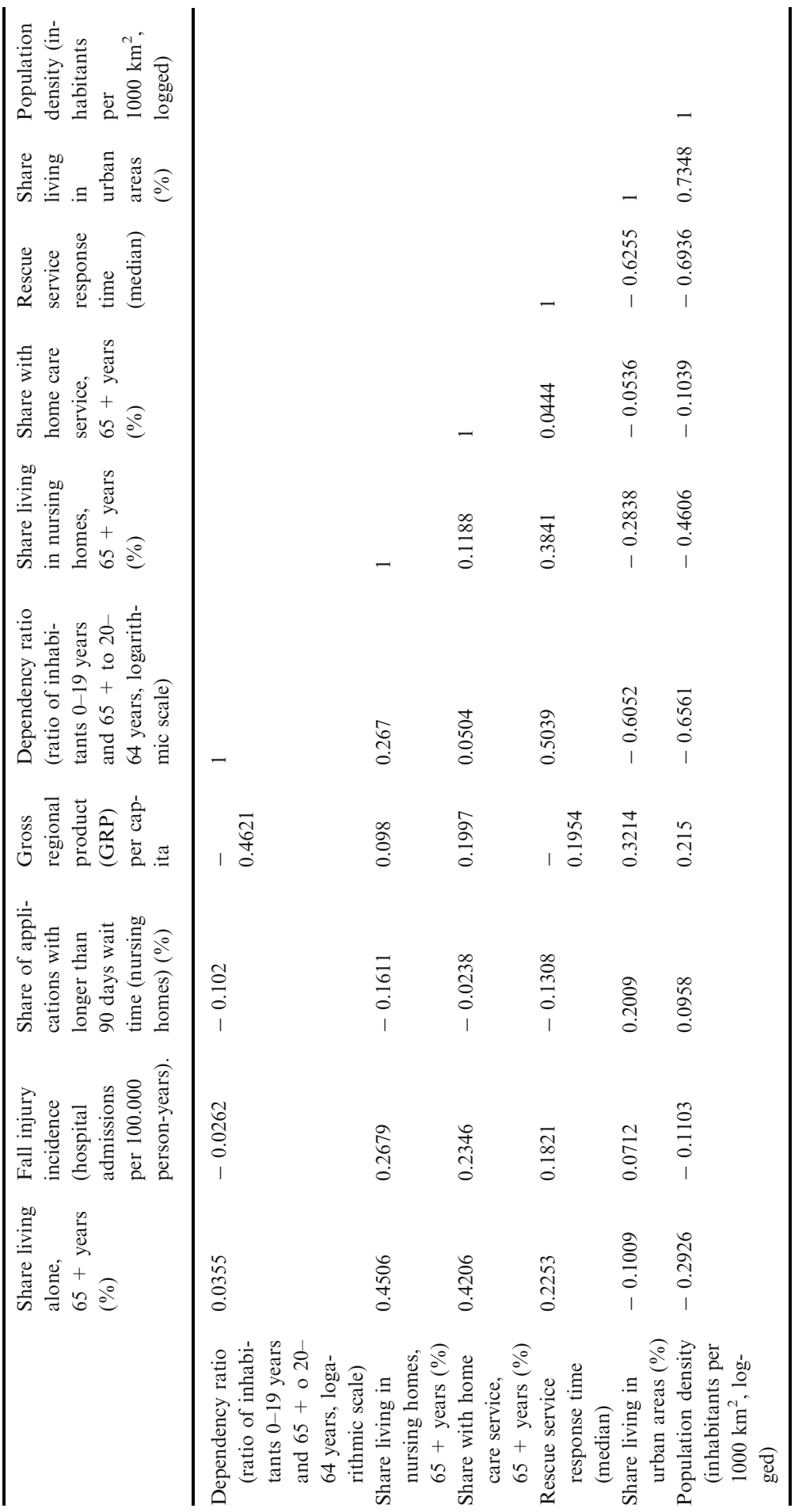




\section{ELECTRONIC SUPPLEMENTARY MATERIAL}

The online version of this article (https://doi.org/10.1007/s10694-020-00997-9) contains supplementary material, which is available to authorized users.

\section{References}

1. Jonsson A, Runefors M, Särdqvist S, Nilson F (2016) Fire-related mortality in Sweden: temporal trends 1952 to 2013. Fire Technol 52(6):1697-1707

2. Marshall SW, Runyan CW, Bangdiwala SI, Linzer MA, Sacks JJ, Butts JD (1998) Fatal residential fires: who dies and who survives?. JAMA 279(20):1633-1637

3. Istre GR, McCoy MA, Osborn L, Barnard JJ, Bolton A (2001) Deaths and injuries from house fires. N Engl J Med 344(25):1911-1916

4. Oecd. Emerging risks in the 21st century - an agenda for action. OECD2003, Paris Contract No.: Report

5. Sekizawa A (2015) Challenges in fire safety in a society facing a rapidly aging population. Fire Prot Eng 2015(1). https://www.sfpe.org/page/FPE_2015_Q1_3

6. Nilson F, Bonander C, Jonsson A (2015) Differences in determinants amongst individuals reporting residential fires in Sweden: results from a cross-sectional study. Fire Technol 51(3):615-626

7. Gilbert SW, Butry DT (2017) Identifying vulnerable populations to death and injuries from residential fires. Injury Prev. https://doi.org/10.1136/injuryprev-2017-042343

8. Runefors M, Johansson N, Van Hees P (2016) How could the fire fatalities have been prevented? An analysis of 144 cases during 2011-2014 in Sweden: an analysis. J Fire Sci 34(6):515-527

9. Jonsson A, Bonander C, Nilson F, Huss F (2017) The state of the residential fire fatality problem in Sweden: epidemiology, risk factors, and event typologies. J Saf Res 62:89-100. https://doi.org/10.1016/j.jsr.2017.06.008

10. Jonsson A, Jaldell H (2019) Identifying sociodemographic risk factors associated with residential fire fatalities: a matched case control study. Injury Prev. https://doi.org/ 10.1136/injuryprev-2018-043062

11. Jennings CR (1999) Socioeconomic characteristics and their relationship to fire incidence: a review of the literature. Fire Technol 35(1):7-34

12. Chandler SE, Chapman A, Hollington SJ (1984) Fire incidence, housing and social conditions - the urban situation in Britain. Fire Prev 172:15-20

13. Duncanson M, Woodward A, Reid P (2002) Socioeconomic deprivation and fatal unintentional domestic fire incidents in New Zealand 1993-1998. Fire Saf J 37(2):165-179

14. Xiong L, Bruck D, Ball M (2015) Comparative investigation of 'survival' and fatality factors in accidental residential fires. Fire Saf J 73:37-47

15. Ballard JE, Koepsell TD, Rivara F (1992) Association of smoking and alcohol drinking with residential fire injuries. Am J Epidemiol 135(1):26-34

16. Berl WG, Halpin BM (1978) Human fatalities from unwanted fires. US Department of Commerce, National Institute of Standards and Technology, Gaithersburg

17. Jonsson A (2018) Dödsbränder i Sverige (Fire-Related Deaths in Sweden). Karlstad University, Karlstad

18. De Jong Gierveld J, Van Tilburg T (1999) Living arrangements of older adults in the Netherlands and Italy: coresidence values and behaviour and their consequences for loneliness. J Cross Cult Gerontol 14(1):1-24 
19. Fernandez-Carro C (2016) Ageing at home, co-residence or institutionalisation? Preferred care and residential arrangements of older adults in Spain. Ageing Soc 36(3):586-612

20. Iacovou M (2000) The living arrangements of elderly Europeans. No. 2000-09. ISER Working Paper Series

21. Da Roit B (2010) Strategies of care: changing elderly care in Italy and the Netherlands. Amsterdam University Press, Amsterdam

22. Jaldell H (2017) How important is the time factor? Saving lives using fire and rescue services. Fire Technol 53(2):695-708

23. Knight K (2013) Facing the future: findings from the review of efficiencies and operations in fire and rescue authorities in England. London Communities and Local Government Publications, London

24. Sund B, Jaldell H (2018) Security officers responding to residential fire alarms: estimating the effect on survival and property damage. Fire Saf J 97:1-11

25. Kaiser HF (1958) The varimax criterion for analytic rotation in factor analysis. Psychometrika 23(3):187-200

26. Clare J, Jennings C, Garis L (2018) Smoke alarm response time: examining the relationship between working smoke alarms, fire service response times and fire outcomes. University of the Fraser Valley, Abbotsford

27. Nilson F, Bonander C (2020) Household fire protection practices in relation to sociodemographic characteristics: evidence from a Swedish national survey. Fire Technol 56:1077-1098. https://doi.org/10.1007/s10694-019-00921-w

28. Smas L (2018) Urbanisation - Nordic geographies of urbanisation. In Grunfelder J, Rispling L, Norlén G (eds) State of the Nordic Region 2018, Nordic Council of Ministers. Copenhagen K. https://doi.org/10.6027/4051794a-en

29. Lindblad S, Tynelius U, Danell T, Pichler W, Anderstig C (2015) Demografins regionala utmaningar (The Challanges in Regional Demographics), SOU 2015:101 (in Swedish). https://www.regeringen.se/contentassets/15c00134b8b4439185d351b14765da2a/de mografins-regionalautmaningar-sou-2015101

30. Ahrens M (2017) US experience with sprinklers. National Fire Protection Association. Research, Data and Analytics Division, Quincy

31. Jaldell H (2012) Kostnadsnyttoanalyser-Sprinkler i särskilda boenden för äldre. Myndigheten för Samhällskydd och Bredskap, Karlstad

32. Runefors M, Johansson N, van Hees P (2017) The effectiveness of specific fire prevention measures for different population groups. Fire Saf J 91:1044-1050

Publisher's Note Springer Nature remains neutral with regard to jurisdictional claims in published maps and institutional affiliations. 